\title{
Faktor-Faktor yang berhubungan dengan Kejadian Stunting pada Balita Usia 24-59 Bulan dari Keluarga Petani di Wilayah Kerja Puskesmas Gunung Labu Kabupaten Kerinci
}

\author{
Asparian $^{1}$, Enda Setiana $^{2}$, Evy Wisudariani $^{3}$ \\ Fakultas Kedokteran dan Ilmu Kesehatan, Universitas Jambi \\ E-mail : asparian@unja.ac.id
}

Submitted : 08/08/2020

Accepted: 22/08/2020

Published: 07/09/2020

\begin{abstract}
Stunting is a state of height index according to age under -2 SD according to WHO standards. Nutrition problems in farmers can occur due to poverty which is the root of nutrition problems. The purpose of this study was to determine the factors associated with the incidence of stunting in children aged 24-59 months from farming families in the Gunung Labu Primary Health Care in Kerinci Regency. Method:The design of this study was cross sectional. The total population in this study was 1,422 toddlers, while the sample in this study was 98 toddlers from farming families. Analysis used the Chi-Square test and Multiple Logistic Regression. Result :This study found the prevalence of stunting in infants $32.34 \%$. Factors related to the incidence of stunting in infants were household level food security and mother's education level. The most dominant factor related to the incidence of stunting in infants was household-level food security $(O R=4,722 ; 95 \% C I=$ 1,599-13,941). Households ware encouraged to use home yards as a place to meet food needs and provide a variety of foods and balanced nutrition for infants so that nutritional needs can be met.
\end{abstract}

Keywords: farmer, HDDS, parenting, stunting, toddler

\begin{abstract}
Abstrak
Stunting merupakan suatu keadaan indeks tinggi badan menurut umur berada dibawah -2 SD berdasarkan standar WHO. Permasalahan gizi pada petani dapat terjadi karena faktor kemiskinan yang merupakan akar permasalahan gizi. Tujuan dari penelitian ini adalah untuk mengetahui faktor-faktor yang berhubungan dengan kejadian stunting pada balita usia 24-59 bulan dari keluarga petani di Wilayah Kerja Puskesmas Gunung Labu Kabupaten Kerinci. Desain penelitian ini adalah cross sectional (potong lintang). Jumlah populasi dalam penelitian ini adalah 1.422 balita, sedangkan sampel dalam penelitian ini adalah 98 balita dari keluarga petani. Analisis menggunakan uji Chi-Square dan Regresi Logistik Ganda. Hasil penelitian ini menemukan prevalensi kejadian stunting pada balita 32,34\%, Faktor yang berhubungan dengan kejadian stunting pada balita adalah ketahanan pangan tingkat rumah tangga dan tingkat pendidikan ibu. Faktor paling dominan yang berhubungan dengan kejadian stunting pada balita adalah ketahanan pangan tingkat rumah tangga $(\mathrm{OR}=4,722 ; 95 \% \mathrm{CI}=1,599-13,941)$. Rumah tangga dianjurkan agar memanfaatakan lahan pekarangan rumah sebagai salah satu wadah untuk memenuhi kebutuhan pangan dan memberikan makanan yang beragam dan bergizi seimbang kepada balita sehingga kebutuhan zat gizi dapat terpenuhi.
\end{abstract}

Kata Kunci: Stunting, Balita, HDDS, Pola Asuh, Petani

\section{PENDAHULUAN}

Pembangunan manusia merupakan hal yang sangat penting untuk diperhatikan. Upaya pembangunan manusia harus dilakukan sejak dini yaitu dimulai saat anak berada dalam kandungan dan usia balita. Agar terwujudnya pembangunan manusia seutuhnya salah satu hal yang dapat dilakukan ialah dengan perbaikan dan peningkatan gizi serta kesehatan. Salah satu aspek penentu sumberdaya manusia adalah gizi, pemenuhan kebutuhan gizi akan berdampak pada kondisi kesehatan seseorang, dan sebaliknya dimana status kesehatan akan berdampak pada status gizi seseorang (Sulistyoningsih, 2012).

Permasalahan gizi di Indonesia juga dialami oleh kelompok balita. Balita 
merupakan salah satu kelompok usia yang rentan mengalami permasalahan gizi dan penyakit. Permasalahan gizi pada balita sering dijumpai karena pada kelompok usia tersebut merupakan kelompok usia yang sedang mengalami pertumbuhan yang cukup pesat. Balita usia 24-59 bulan akan memiliki aktivitas yang semakin banyak seperti bermain, mereka sudah dapat menentukan dan memilih makanan yang disukai, sehingga pada masa ini balita membutuhkan zat-zat gizi yang cukup untuk memenuhi kebutuhan gizinya (Moehji, 2016).

Kebutuhan gizi dapat terpenuhi dengan baik jika ada keseimbangan antara asupan zat gizi dan pengeluarannya. Zat gizi dapat diperoleh dari makanan yang dikonsumsi oleh balita agar seseorang balita dapat tumbuh dan berkembang dengan baik maka makanan yang dikonsumsi sebaiknya beragam jenisnya, cukup jumlah serta porsinya, higienis dan aman, makan dilakukan secara teratur dan dengan cara yang baik. Status gizi balita merupakan hal yang perlu mendapatkan perhatian khusus dari orang tua, terutama pada masa balita yang merupakan periode emas perumbuhan dan perkembangan anak, kekurangan gizi pada periode emas dapat menyebabkan seorang balita mengalami hambatan dalam perkembangan otak (Proverawati and Wati, 2011).

Susteinable Development Goals (SDGs) 2030 tentang gizi masyarakat adalah mengakhiri segala bentuk malnutrisi, dan mencapai target Internasional 2025 untuk penurunan stunting dan wasting pada balita (Kemenkes RI, 2015). Target SDGs tersebut juga disejalankan dengan Rencana Pembangunan Jangka Menengah (RPJMN) Indonesia 2020-2024 menyebutkan bahwa, target penurunan prevalensi stunting pada balita menjadi 19\%, sedangkan untuk target penurunan wasting pada balita adalah $7 \%$ (Bappenas, 2019a). Data WHO menunjukan permasalahan gizi pada balita diantaranya menunjukan Indonesia merupakan negara yang menempati posisi ketiga negara dengan prevalensi stunting tertinggi setelah negara Timor Leste dan India, dengan prevalensi pada tahun 2017 sebesar 36,4\%, hal ini menunjukan bahwa stunting merupakan masalah gizi yang serius dan eharus mendapatkan perhatian khusus yang melibatkan berbagai sektor (Kemenkes RI, 2018b).

Berdasarkan data Riset Kesehatan Dasar 2018 diketahui bahwa prevalensi anak balita dengan status gizi buruk dan gizi kurang (underweigh) adalah 17,7\%, data ini menunjukan penurunan dibandingkan dengan tahun 2013 yaitu sebesar $19,6 \%$. Status gizi kurus dan sangat kurus (wasting) turun dari $12,1 \%$ pada tahun 2013 menjadi 10,2\% pada tahun 2018. Status gizi pendek dan sangat pendek (stunting) pada tahun 2018 juga telah mengalami penurunan yaitu sebesar $37,2 \%$ pada tahun 2013 menjadi 30,8\% pada tahun 2018 (Balitbang Kemenkes RI, 2018a). Meskipun permasalahan gizi nasional telah menunjukan penurunan secara kuantitas namun secara kualitas tidak terdapat perubahan pada permasalahan gizi balita salah satunya di Provinsi Jambi.

Provinsi Jambi merupakan salah satu Provinsi yang mengalami peningkatan permasalah gizi pada balita. Masalah gizi buruk dan gizi kurang pada balita di Provinsi Jambi meningkatan dari tahun sebelumnya, yaitu dari $13,5 \%$ pada tahun 2017 menjadi 15,7\% pada tahun 2018. Status gizi kurus dan sangat kurus pada balita di Provinsi Jambi juga ikut mengalami peningkatan dari $10,6 \%$ menjadi $12 \%$. Selanjutnya untuk kategori status gizi pendek dan sangat pendek pada balita di Provinsi Jambi juga mengalami peningkatan dari $24,2 \%$ pada tahun 2017 menjadi 30,2\% pada tahun 2018 (Kemenkes RI, 2018a). Peningkatan masalah gizi pendek dan sangat pendek ini menyebabkan Provinsi Jambi masuk 
kedalam 18 Provinsi dengan prevalensi gizi pendek dan sangat pendek diatas rata-rata nasional. Berdasarkan data riset kesehatan dasar 2018 diketahui bahwa prevalensi kejadian stunting pada balita disetiap kabupaten/kota yang ada di Provinsi Jambi rata-rata masih diatas $20 \%$ berdasarkan kriteria WHO yang berarti bahwa masalah stunting di Provisni Jambi merupakan permasalahan gizi yang cukup serius. Salah satu Kabupaten yang memiliki prevalensi kejadian stunting pada balita cukup tinggi adalah Kabupaten Kerinci (42,41\%), Kabupaten Kerinci termasuk kedalam kabupaten lokasi fokus pencegahan stunting pada tahun 2020(Balitbang Kemenkes RI, 2018b).

Berdasarkan data penentuan status gizi balita di Puskesmas Gunung Labu 2019 diketahui bahwa prevalensi permasalahan gizi balita di Puskesmas Gunung Labu adalah underweigh 5,5\%, wasting 3,83\%, dan stunting $27,12 \%$. Namun permasalahan gizi yang paling banyak terjadi adalah pendek dan sangat pendek (stunting) dengan prevalensi 27,12\% (Puskesmas Gunung Labu, 2019a). Dari data Internasional, Nasional, Provinsi, Kabupaten dan data Puskesmas Gunung Labu dapat diketahui bahwa permasalahan gizi yang paling banyak ditemui pada balita adalah stunting.

Puskesmas Gunung Labu terletak di Kecamatan Kayu Aro Barat. Masyarakat Kecamatan Kayu Aro Barat mayoritas berkerja sebagai petani baik petani pemilik lahan maupun buruh tani. Hasil tani di Kecamatan Kayu Aro barat berupa jagung, padi sawah, kacang tanah, ubi jalar, ubi kayu, dan kedelai (BPS Kabupaten Kerinci, 2019).

Sektor pertanian memiliki pengaruh terhadap masalah gizi terutama produksi pangan dan ketahanan pangan rumah tangga. Permasalahan gizi pada keluarga petani tidak akan terjadi jika pangan dapat diproduksi dalam jumlah dan ragam yang mencukupi, dan bahan pangan yang tersedia cukup di tingkat rumah tangga serta petani memiliki cukup uang untuk membeli kebutuhan pangan yang tidak ditanam, namun permasalahan gizi pada petani dapat terjadi karena faktor kemiskinan (Safitri, Pengestuti and Aruben, 2017).

Faktor yang menyebabkan permasalah gizi pada balita terdiri dari faktor langsung dan faktor tidak langsung. Faktor langsung dari pemasalahan gizi adalah makanan yang dikonsumsi dan status infeksi, sedangkan faktor tidak langsung dari permasalahan gizi adalah ketersediaan dan pola konsumsi rumah tangga, pola asuh (pola asuh pemberian makan), pelayanan kesehatan dan kesehatan lingkungan. Karakteristik keluarga juga merupakan faktor yang mempengaruhi status gizi balita, diantaranya adalah pendapatan rumah tangga, jumlah anggota rumah tangga, pengeluaran pangan rumah tangga, pekerjaan ibu, dan tingkat pendidikan ibu (Jayarni and Sumarmi, 2018).Berdasarkan uraian diatas, maka peneliti tertarik untuk melakukan penelitian faktor-faktor yang berhubungan dengan kejadian stunting pada balita usia 24-59 tahun dari keluarga petani di wilayah kerja Puskesmas Gunung Labu Kabupaten Kerinci.

\section{METODE PENELITIAN}

Jenis penelitian ini adalah penelitian kuantitatif dengan menggunakan desain cross sectional (potong lintang). Populasi dalam penelitian ini adalah seluruh balita usia 24-59 bulan yang berada di Wilayah Kerja Puskesmas Gunung Labu, sebanyak 1.422 balita. Sampel dalam penelitian ini adalah 98 balita dari keluarga petani. Pengambilan sampel dilakukan dengan menggunakan teknik Proportional Random Sampling.

Pengumpulan data dilakukan pada bulan Februari-Maret 2020. Variabel independen dalam penelitian ini adalah 
ketahanan pangan tingkat rumah tangga, pola asuh pemberian makan, pendapatan rumah tangga, jumlah anggota rumah tangga, pengeluaran pangan rumah tangga, pekerjaan ibu, dan tingkat pendidikan ibu. Sedangan variabel dependen penelitian ini adalah kejadian stunting. Analisis menggunakan uji Chi-Square dan Regresi Logistik Ganda.

\section{HASIL DAN PEMBAHASAN}

\section{Analisi Univariat}

Hasil analisis univariat diperoleh bahwa rata-rata responden berusia 20-35

Tabel 1. Distribusi Responden Berdasarkan Karakteristik Sosiodemografi di Wilayah Kerja Puskesmas Gunung Labu Kabupaten Kerinci

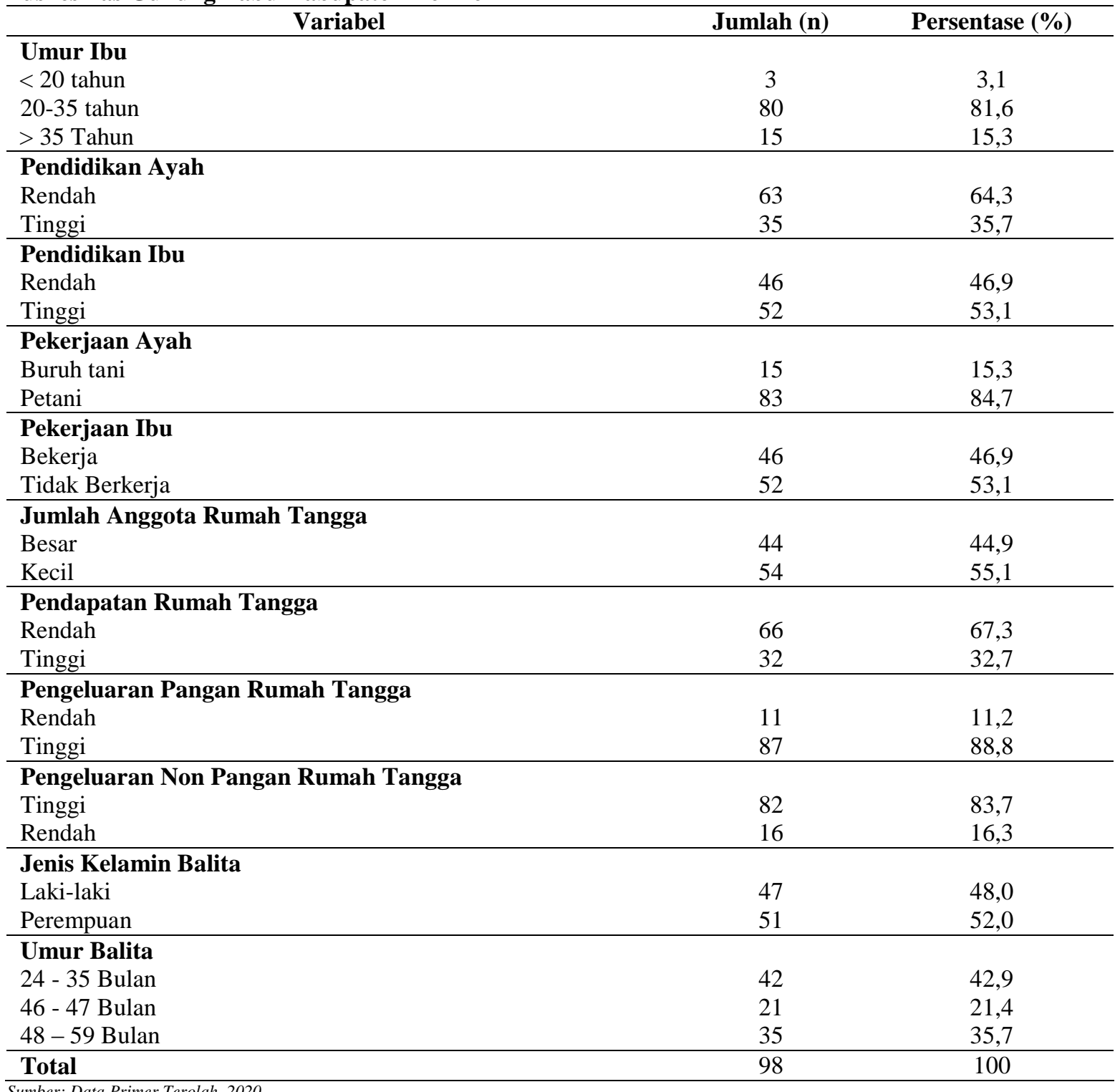

tahun (81,6\%). Distribusi Responden Berdasarkan Karakteristik Sosiodemografi di Wilayah Kerja Puskesmas Gunung Labu Kabupaten Kerinci dapat dilihat pada tabel 1. Responden yang memiliki pendidikan tinggi sebesar $(53,1 \%)$, sedangkan pendidikan kepala keluarga mayoritas tergolong rendah $(54,3 \%)$. Kepala keluarga dari responden mayoritas memiliki pekerjaan sebagai petani $(84,7 \%)$. Pekerjaan responden rata-rata adalah tidak berkerja $(53,1 \%)$. 
Responden mayoritas memiliki jumlah anggota rumah tangga tergolong kecil $(55,1 \%)$. Pendapatan rumah tanggga responden mayoritas tergolong rendah $(67,3 \%)$. Sedangkan pengeluaran pangan tingkat rumah tangga dari responden mayoritas masuk dalam kategori tinggi $(88,8 \%)$. Pengeluaran non pangan tingkat rumah tangga dari responden mayoritas tergolong tinggi $(83,7 \%)$. Responden penelitian mayoritas memiliki balita dengan jenis kelamin perempuan (52,0\%). Sedangkan mayoritas usia balita dari responden adalah 24-35 bulan (42,9\%).

Berdasarkan tabel 2 diatas dapat dilihat bahwa ketahanan pangan responden mayoritas berada pada kategori tinggi $(73,5 \%)$. Pola asuh pemberian makan pada balita mayoritas dalam kategori cukup $(39,8$ $\%)$. Mayoritas responden memiliki pendapatan rendah $(67,3 \%)$. Selain itu jumlah anggota rumah tangga dari responden mayoritas kecil (55,1\%). Pengeluaran pangan rumah tangga dari responden mayoritas berada pada kategori tinggi $(88,8 \%)$. Pekerjaan ibu mayoritas berada pada kategori tidak berkerja $(53,1 \%)$. Tingkat pendidikan ibu mayoritas berada pada kategori tinggi $(53,1 \%)$.

Proporsi kejadian stunting pada balita stunting $(46,9 \%)$ dan balita dengan status gizi normal (52\%).prevalensi kejadian stunting pada balita usia 24-59 bulan di Wilayah Kerja Puskesmas Gunung Labu adalah $(32,34 \%)$.

Tabel 2 Distribusi Responden Berdasarkan Variabel Penelitian di Wilayah Kerja Puskesmas Gunung Labu Kabupaten Kerinci

\begin{tabular}{lcc}
\hline \multicolumn{1}{c}{ Variabel } & Jumlah (n) & Persentase (\%) \\
\hline Ketahanan Pangan & 26 & 26,5 \\
Rendah & 72 & 73,5 \\
Tinggi & & \\
\hline Pola asuh Pemberian Makan & 35 & 35,7 \\
Kurang & 39 & 39,8 \\
Cukup & 24 & 24,5 \\
Baik & & \\
\hline Pendapatan Rumah Tangga & 66 & 67,3 \\
Rendah & 32 & 32,7 \\
Tinggi & & \\
\hline Jumlah Anggota Rumah Tangga & 44 & 44,9 \\
Besar & 54 & 55,1 \\
Kecil & & \\
\hline Pengeluaran Pangan Rumah Tangga & 11 & 88,8 \\
Rendah & 87 & \\
Tinggi & & 46,9 \\
\hline Pekerjaan Ibu & 46 & 53,1 \\
Bekerja & 52 & 46,9 \\
Tidak Berkerja & & 53,1 \\
\hline Tingkat Pendidikan Ibu & & 100 \\
Rendah & & \\
Tinggi & 46 & \\
\hline Total & 52 & \\
\hline Sumber: Data Primer Terolah, 2020 & 98 & \\
\hline
\end{tabular}




\section{ANALISIS BIVARIAT}

Tabel 3 Hasil Analisis Bivariat Faktor-Faktor yang Berhubungan dengan Kejadian Stunting pada Balita Usia 24-59 Bulan dari Keluarga Petani di Wilayah Kerja Puskesmas Gunung Labu, Kabupaten Kerinci

\begin{tabular}{|c|c|c|c|c|c|c|c|c|}
\hline \multirow[t]{3}{*}{ Variabel } & \multicolumn{4}{|c|}{ Status Gizi (TB/U) } & \multirow{2}{*}{\multicolumn{2}{|c|}{ Total }} & \multirow[t]{3}{*}{ PR (95\% CI) } & \multirow[t]{3}{*}{ P-value } \\
\hline & \multicolumn{2}{|c|}{ Stunting } & \multicolumn{2}{|c|}{ Normal } & & & & \\
\hline & $\mathbf{N}$ & $\%$ & $\mathbf{N}$ & $\%$ & $\mathbf{N}$ & $\%$ & & \\
\hline \multicolumn{9}{|l|}{ Ketahanan Pangan } \\
\hline Rendah & 19 & 73,1 & 7 & 26,9 & 26 & 100 & $2,321(1,202-4,483)$ & $0,004 *$ \\
\hline Tinggi & 27 & 37,5 & 45 & 62,5 & 72 & 100 & & \\
\hline \multicolumn{9}{|c|}{ Pola Asuh Pemberian Makan } \\
\hline Cukup dan Kurang & 41 & 55,4 & 33 & 44,6 & 35 & 100 & $1,775(1,281-2,461)$ & $0,007 *$ \\
\hline Baik & 5 & 20,8 & 19 & 79,2 & 39 & 100 & & \\
\hline \multicolumn{9}{|c|}{ Pendapatan Rumah Tangga } \\
\hline Rendah & 36 & 54,5 & 30 & 45,5 & 66 & 100 & $1,513(1,063-2,152)$ & 0,051 \\
\hline Tinggi & 10 & 31,3 & 22 & 68,8 & 32 & 100 & & \\
\hline \multicolumn{9}{|c|}{ Jumlah Anggota Rumah Tangga } \\
\hline Besar & 25 & 56,8 & 19 & 43,2 & 44 & 100 & $1,415(0,948-2,112)$ & 0,117 \\
\hline Kecil & 21 & 38,9 & 33 & 61,1 & 54 & 100 & & \\
\hline \multicolumn{7}{|c|}{ Pengeluaran Pangan Rumah Tangga } & & \\
\hline Rendah & 5 & 45,5 & 6 & 54,5 & 11 & 100 & $0,969(0,546-1,722)$ & 1,000 \\
\hline Tinggi & 41 & 47,1 & 46 & 52,9 & 87 & 100 & & \\
\hline \multicolumn{9}{|l|}{ Pekerjaan Ibu } \\
\hline Bekerja & 23 & 50,0 & 23 & 50,0 & 46 & 100 & $1,115(0,765-1,626)$ & 0,713 \\
\hline Tidak Bekerja & 23 & 44,2 & 29 & 55,8 & 52 & 100 & & \\
\hline \multicolumn{9}{|c|}{ Tingkat Pendidikan Ibu } \\
\hline Rendah & 25 & 54,3 & 21 & 45,7 & 46 & 100 & $1,306(0,887-1,922)$ & 0,238 \\
\hline Tinggi & 21 & 40.4 & 31 & 59,6 & 52 & 100 & & \\
\hline
\end{tabular}

Berdasarkan tabel 3 diatas dapat dilihat bahwa terdapat perbedaan proporsi balita dengan ketahanan pangan rendah mengalami stunting sebesar $73,1 \%$ serta balita dengan ketahanan pangan tinggi $37,5 \%$ mengalami stunting. Hal ini menunjukan mayoritas balita stunting memiliki ketahanan pangan tingkat rumah tangga yang rendah. Ada hubungan yang signifikan antara ketahanan pangan dengan kejadian stunting, dimana balita dengan ketahanan pangan tingkat rumah tangga rendah memiliki risiko 2,321 kali untuk mengalami stunting dibandingkan dengan balita yang memiliki ketahanan pangan tingkat rumah tangga tinggi.

Ada perbedaan proporsi pola asuh pemberian makan pada balita stunting terdapat 55,4 \% yang memiliki pola asuh pemberian makan cukup dan kurang, serta terdapat $20,8 \%$ balita stunting yang memiliki pola asuh pemberian makan yang baik. Hal ini menunjukan mayoritas balita stunting memiliki pola asuh pemberian makan yang cukup dan kurang. Berdasarkan hasil uji statistik diketahui terdapat hubungan antara pola asuh pemberian makan yang cukup dan kurang dengan kejadian stunting pada balita, dimana balita dengan pola asuh pemberian makan yang cukup dan kurang akan memiliki risiko 1,775 kali mengalami stunting dibandingkan dengan balita yang mendapatkan pola asuh pemberian makan yang baik.

Terdapat perbedaan proposi balita dengan pendapatan rumah tangga rendah $54,5 \%$ mengalami stunting sedangkan balita dengan pendapatan rumah tangga tinggi 31,3\% mengalami stunting. Hal ini 
menunjukan mayoritas balita stunting berasal dari rumah tangga yang pendapatannya rendah.Tidak terdapat hubungan yang signifikan antara pendapatan rumah tangga dengan kejadian stunting. Namun, balita dengan pendapatan rumah tangga rendah akan memiliki risiko1,513 kali untuk mengalami stunting dibandingkan dengan balita dengan pendapatan rumah tangga tinggi.

Terdapat perbedaan proposi balita dengan jumlah anggota rumah tangga besar $56,8 \%$ mengalami stunting sedangkan balita dengan jumlah anggota rumah tangga kecil 38,9 \% mengalami stunting. Hal ini menunjukan mayoritas balita stunting memiliki jumlah anggota rumah tangga yang besar. Tidak terdapat hubungan yang signifikan antara jumlah anggota rumah tangga dengan kejadian stunting. Namun, balita dengan jumlah anggota rumah tangga besar akan memiliki risiko 1,415 kali untuk mengalami stunting dibandingkan dengan balita dengan jumlah anggota rumah tangga kecil.

Ada perbedaan proposi balita dengan pengeluaran pangan rumah tangga rendah $45,5 \%$ mengalami stunting sedangkan balita dengan pengeluaran pangan rumah tangga tinggi $47,1 \%$ mengalami stunting.Hal ini menunjukan mayoritas balita stunting memiliki pengeluaran pangan rumah tangga yang tinggi. Tidak terdapat hubungan yang signifikan antara pengeluaran pangan rumah tangga dengan kejadian stunting. pengeluaran pangan yang rendah akan menurunkan risiko terjadinya stunting pada balita.

Terdapat perbedaan proporsi balita dengan ibu berkerja 50,0 \% mengalami stunting sedangkan balita dengan ibu tidak berkerja 44,2 \% mengalami stunting. Hal ini menunjukan mayoritas balita stunting memiliki ibu yang berkerja. Tidak terdapat hubungan yang signifikan antara pekerjaan ibu dengan kejadian stunting. Namun, balita dengan ibu berkerja akan memiliki risiko
1,115 kali untuk mengalami stunting dibandingkan dengan balita dengan ibu tidak berkerja.

Ada perbedaan proporsi balita dengan tingkat pendidikan ibu rendah 54,3 \% mengalami stunting sedangkan balita dengan tingkat pendidikan ibu tinggi 40,4 $\%$ mengalami stunting. Hal inimenunjukan mayoritas balita stunting memiliki ibu dengan tingkat pendidikan yang rendah. Tidak terdapat hubungan yang signifikan antara tingkat pendidikan ibu dengan kejadian stunting. Namun, balita dengan tingkat pendidikan ibu rendah akan memiliki risiko 1,306 kali untuk mengalami stunting dibandingkan dengan balita dengan tingkat pendidikan ibu tinggi.

\section{ANALISIS MULTIVARIAT}

Berdasarkan hasil analisis regresi logistik sederhana diketahui bahwa variabel yang masuk kedalam kandidat multivariat adalah variabel ketahanan pangan rumah tangga, pola asuh pemberian makan, pendapatan rumah tangga, jumlah anggota rumah tangga, dan tingkat pendidikan ibu.

Berdasarkan tabel 4 dapat dilihat bahwa ketahanan pangan rumah tangga dan tingkat pendidikan ibu memiliki hubungan bermakna secara statistik ( $p$-value < 0,05) dengan $(\mathrm{OR}=$ 4,722; 95\%CI 1,599-13,941) dan $(\mathrm{OR}=2,554$; 95\% CI 1,008-6,468). Berdasarkan hasil analisis multivariat ini juga dapat diketahui bahwa variabel yang paling dominan berperan terhadap kejadian stunting pada balita usia 2459 bulan di Wilayah Kerja Puskesmas Gunung Labu adalah ketahanan pangan rumah tangga.

\section{a. Hubungan Ketahanan Pangan dengan Kejadian Stunting}

Hasil analisis multivariat menunjukan bahwa terdapat hubungan yang signifikan antara ketahanan pangan rumah tangga dengan kejadian stunting pada balita $(P$ value $=0,005)$ serta balita yang memiliki ketahanan pangan rumah tangga rendah akan memiliki risiko 4,722 kali lebih besar untuk mengalami stunting dibandingkan 
Tabel 4 Permodelan Multivariat

\begin{tabular}{|c|c|c|c|c|c|c|c|c|c|c|c|c|}
\hline \multirow{2}{*}{ Variabel } & \multicolumn{2}{|c|}{ Model 1} & \multicolumn{2}{|c|}{ Model II } & \multicolumn{2}{|c|}{ Model III } & \multicolumn{2}{|c|}{ Model IV } & \multicolumn{2}{|c|}{ Model V } & \multicolumn{2}{|c|}{ Model VI } \\
\hline & $\mathbf{P}$ & OR & $\mathbf{P}$ & OR & $\mathbf{p}$ & OR & $\mathbf{P}$ & OR & $\mathbf{P}$ & OR & $\mathbf{p}$ & OR \\
\hline Ketahana & 0,004 & 5,10 & 0,003 & 5,24 & 0,005 & 4,72 & 0,004 & 4,83 & 0,011 & 3,80 & 0,005 & 4,72 \\
\hline $\begin{array}{l}\text { n Pangan } \\
\text { Rumah } \\
\text { Tangga }\end{array}$ & $*$ & 5 & $*$ & 8 & $*$ & 2 & $*$ & 8 & $*$ & 3 & $*$ & 2 \\
\hline Pola & 0.086 & 3,03 & 0,021 & 3,90 & 0,065 & 3,22 & 0,016 & 4,07 & 0,051 & 3,36 & 0,065 & 3,22 \\
\hline $\begin{array}{l}\text { Asuh } \\
\text { Pemberia } \\
\text { n Makan }\end{array}$ & & 8 & $*$ & 9 & & 8 & $*$ & 6 & & 7 & & 8 \\
\hline $\begin{array}{l}\text { Pendapata } \\
\text { n Rumah } \\
\text { Tangga }\end{array}$ & 0,365 & $\begin{array}{c}1,65 \\
8\end{array}$ & - & - & 0,381 & $\begin{array}{c}1,61 \\
3\end{array}$ & - & - & 0,499 & $\begin{array}{c}1,43 \\
0\end{array}$ & 0,381 & $\begin{array}{c}1,61 \\
3\end{array}$ \\
\hline $\begin{array}{l}\text { Jumlah } \\
\text { Anggota } \\
\text { Keluarga }\end{array}$ & 0,154 & $\begin{array}{c}1,94 \\
8\end{array}$ & 0,159 & $\begin{array}{c}1,92 \\
6\end{array}$ & - & - & - & - & - & - & - & - \\
\hline $\begin{array}{l}\text { Tingkat } \\
\text { Pendidika } \\
\text { n Ibu }\end{array}$ & 0,077 & $\begin{array}{c}2,36 \\
0\end{array}$ & 0.090 & $\begin{array}{c}2,25 \\
4\end{array}$ & $\begin{array}{c}0,048 \\
*\end{array}$ & $\begin{array}{c}2,55 \\
4\end{array}$ & 0,057 & $\begin{array}{c}2,44 \\
0\end{array}$ & - & - & $\begin{array}{c}0,048 \\
*\end{array}$ & $\begin{array}{c}2,55 \\
4\end{array}$ \\
\hline
\end{tabular}

Sumber : Data Primer Terolah, $2020 *$ )Signifikan pada $\alpha=0,05$

dengan balita yang memiliki ketahanan pangan rumah tangga yang tinggi $(95 \% \mathrm{CI}$ 1,599-13,941). Hasil analisis bivariat memunjukan proporsi kejadian stunting pada balita dari ketahanan pangan rumah tangga rendah adalah $73,1 \%$, sedangkan pada balita dengan tingkat ketahanan pangan rumah tangganya tinggi adalah $37,5 \%$.

Penelitian ini sejalan dengan penelitian yang dilakukan di Kacamatan Bayat, Kabupaten Klaten tahun 2018 yang menunjukan terdapat hubungan antara ketahanan pangan yang diukur menggunkan skor HDDS dengan kejadian stunting pada balita $(p$-value $=0,024)$ penelitian ini menyatakan bahwa $85,4 \%$ balita yang mengalami stunting memiliki konsumsi makanan yang tidak beragam atau ketahanan pangan yang rendah (Widyaningsih and Anantanyu, 2018).

Rumah tangga yang ada di Wilayah kerja Puskesmas Gunung Labu yang memiliki ketahanan pangan tinggi $(67,3 \%)$ memanfaatkan lahan pekarangan rumah untuk menanam sayur atau buah-buahan lokal, sebagai salah satu upaya memenuhi kebutuhan pangan. Selain itu rumah tangga yang memiliki ketahanan pangan rumah tangga yang tinggi mayoritas memiliki lahan pertanian $(78,7 \%)$, hal ini dapat disebabkan karena rumah tangga yang memiliki lahan pertanian akan cenderung lebih mudah mendapatkan bahan pangan terutama bahan pangan yang ditanam dilahan miliknya sendiri.

Berdasarkan grafik diatas dapatkan informasi bahwa rumah tangga yang memiliki balita dengan status gizi normal memiliki asupan gizi yang lebih beragam dibandingkan dengan rumah tangga yang memiliki balita yang mengalami stunting. Asupan makanan rumah tangga yang memiliki balitastunting didominasi oleh makanan bersumber energi berupa beras dan mie. Selain itu asupan makanan rumah tangga yang memiliki balita stunting juga didominasi oleh makanan bersumber karbohidrat berupa kentang. Sedangkan makanan yang minoritas dikonsumsi adalah daging, unggas, dan jeroan. Rumah tangga yang memiliki balita stunting memiliki asupan sayuran, buah-buahan, telur, kacang-kacangan, dan susu lebih rendah dibandingkan dengan balita dengan status gizi normal. Pada penelitian ini persentase 
rumah tangga dengan balita stunting yang mengonsumsi ikan dan seafood lebih tinggi dari pada rumah tangga yang memiliki balita dengan status gizi normal, namun hanya memiliki selisih yang kecil $(4,80 \%)$.

\section{b. Hubungan Pola Asuh Pemberian Makan dengan Kejadian Stunting}

Hasil analisis multivariat menunjukan tidak terdapat hubungan yang signifikan antara pola asuh pemberian makan dengan kejadian stunting pada balita $(P$-value $=$ $0,065)$ serta balita yang memiliki pola asuh pemberian makan yang cukup dan kurang akan memiliki risiko 3,228 kali lebih besar untuk mengalami stunting dibandingkan dengan balita yang memiliki pola asuh pemberian makan yang baik dengan $(95 \%$ CI 0,932-6,1180). Pada analisis bivariat didapatkan hubungan yang signifikan antara pola asuh pemberian makan dengan kejadian stunting pada balita, namun setelah dilakukan analisis multivariat menggunakan regresi logistik hasil ini mengalami perubahan menjadi tidak signifikan.

Penelitian ini sejalan dengan penelitian yang dilakukan pada balita di Kelurahan Depok menunjukan tidak terdapat hubungan yang signifikan antara pola asuh pemberian makan dengan kejadian stunting pada balita ( $p$ value $=0,691$ ). Penelitian ini menunjukan bahwa pola asuh pemberian makan yang diterapkan ibu balita $81,5 \%$ berada pada ketegori baik. Pola asuh lebih berhubungan dengan status gizi balita berdasarkan indeks BB/U (Isnaini and Indrawani, 2014).

Dalam penelitian ini didapati bahwa pola asuh pemberian makan yang dilakukan oleh ibu kepada balitanya mengikuti pola asuh makan yang umum pada masyarakat setempat, ibu memberikan makan kepada balitanya berdasarkan bahan makanan yang tersedia dirumah tangga serta memiliki kebiasaan memberikan makanan yang hanya disukai oleh balitanya saja tanpa memperhatikan keragaman makanan yang dikonsumsi oleh anak sehingga sangat memungkinkan kebutuhan gizi anak tidak terpenuhi.

\section{c. Hubungan Pendapatan Rumah Tangga dengan Kejadian Stunting \\ Hasil penelitian ini menunjukan tidak} terdapat hubungan antara pendapatan rumah tangga dengan kejadian stunting pada balita $(P$-value $=0,051)$ akan tetapi balita dengan pendapatan rumah tangga yang rendah akan memiliki risiko 1,513 kali lebih besar untuk mengalami stunting dibandingkan dengan balita dengan pendapatan rumah tangga yang tinggi dengan (95\% CI 1,063-2,152). Proporsi kejadian stunting pada balita dari keluarga petani di Wilayah Kerja Puskesmas Gunung Labu yang berasal dari pendapatan rumah tangga yang rendah adalah 54,5\%, sedangkan pada balita dengan pendapatan rumah tangga tinggi adalah $31,3 \%$.

Penelitian ini sejalan dengan penelitian yang dilakukan di Kota Semarang dimana didapati bahwa tidak terdapat hubungan antara pendapatan rumah tangga dengan kejadian stunting, hal ini sebabkan karena didapatkan kecenderungan rumah tangga yang mimiliki tingkat pendapatan tinggi lebih banyak yang mengalami stunting, ini sebabkan mayoritas pendapatan digunakan untuk memenuhi kebutuhan non pangan (Aisyah, Suyatno and Rahfiludin, 2019).

Pendapatan rumah tangga yang tinggi pastinya akan mempermudah akses sebuah rumah tangga untuk mendapatkan makanan, namun akses makanan yang baik tidak akan berpengaruh terhadap gizi balita jika pola asuh yang diberikan oleh ibu kurang baik berdasarkan penelitian ini didapati bahwa $75,5 \%$ balita tidak mendapatkan pola asuh pemberian makan yang baik, hal ini tentunya akan berpengaruh terhadap kecukupan gizi balita dan akan menyebabkan terjadinya stunting. 
rendahnya pendapatan rumah tangga dimungkinkan juga diakibatkan karena petani tidak memiliki lahan pertanian sehingga mereka memilih berkerja sebagai buruh tani dengan pendapatan yang minimun.

\section{d. Hubungan Jumlah Anggota Rumah}

\section{Tangga dengan Kejadian Stunting}

Hasil penelitian ini menunjukan tidak terdapat hubungan antara jumlah anggota rumah tangga dengan kejadian stunting pada balita $(P$-value $=0,117)$ akan tetapi balita yang memiliki jumlah anggota rumah tangga besar akan memiliki risiko 1,415 kali lebih besar untuk mengalami stunting dibandingkan dengan balita yang memiliki jumlah anggota rumah tangga yang kecil dengan (95\% CI 0,948-2,112). Proporsi kejadian stunting pada balita usia 24- 59 bulan dari keluarga petani pada jumlah anggota rumah tangga yang besar adalah $56,8 \%$. Sedangkan pada balita yang jumlah anggota rumah tangganya kecil adalah $38,9 \%$.

Penelitian ini sejalan dengan penelitian yang dilakukan Setiawan tahun 2018 yang menyebutkan bahwa tidak terdapat hubungan yang signifikan antara jumlah anggota rumah tangga dengan kejadian stunting pada balita usia 24-59 bulan diwilayah kerja Puskesmas Andalas Kecamatan Padang Timur Kota Padang, ini disebabkan karena banyak faktor yang mempengaruhi status gizi tidak hanya dipengaruhi oleh faktor jumlah anggota rumah tangga saja namun juga dipengaruhi oleh pola asuh, sosial ekonomi keluarga (Setiawan and Machmud, 2018).

Dalam penelitian ini didapati bahwa jumlah anggota rumah tangga tidak dapat menjamin secara mutlak status gizi anggotanya. Jumlah anggota rumah tangga yang besar jika diimbangi dengan asupan gizi yang cukup serta pendapatan rumah tangga yang tinggi sehingga dapat mempermudah untuk memenuhi kebutuhan pangan maka akan mengurangi risiko terjadinya stunting pada balita.

\section{e. Hubungan Pengeluaran Pangan \\ Rumah Tangga dengan Kejadian Stunting}

Hasil penelitian ini menunjukan tidak terdapat hubungan antara pengeluaran pangan rumah tangga dengan kejadian stunting pada balita $(P$-value $=1,000)$ akan tetapi pengeluaran pangan rumah tangga merupakan faktor protektif terhadap kejadian stunting, dengan OR 0,969 yang artinya pengeluaran pangan rumah tangga yang rendah akan menurunkan risiko stunting pada balita dengan (95\% CI 0,5461,722). Proporsi kejadian stunting pada balita dari pengeluaran pangan rumah tangga rendah adalah 45,5\%, sedangkan pada balita dengan pengeluaran pangan rumah tangga tinggi memiliki persentase kejadian stunting sebesar $47,1 \%$.

Penelitian ini sejalan dengan penelitian yang dilakukan pada balita usia 24-59 bulan di Kota Semarang yang menyatakan bahwa tidak terdapat hubungan antara pengeluaran pangan rumah tangga dengan kejadian stunting pada balita ( $p$ value $=0,31$ ), penurunan kualitas konsumsi rumah tangga dicirikan dengan keterbatasan dalam membeli pangan sumber protein, vitamin, dan mineral yang akan berdampak terhadap kekurangan gizi mikro maupun makro (Bening, Margawati and Rosidi, 2015).

Dalam penelitian ini didapati bahwa pengeluaran pangan rumah tangga yang tinggi tidak dapat menjamin terpenuhinya kebutuhan balita, hal ini dikarenakan mayoritas pengeluaran pangan rumah tangga di Wilayah Kerja Puskesmas Gunung Labu tinggi (88,8\%) serta berdasarkan hasil analasis crosstab didapatkan bahwa mayoritas dari responden yang memiliki pengeluaran pangan tinggi memiliki kepala rumah tangga yang merokok $(88,7 \%)$ sehingga tingginya pengeluaran pangan itu tidak hanya 
diperuntukkan untuk kebutuhan makanan dan minum saja tetapi juga untuk membeli rokok.

\section{f. Hubungan Pekerjaan Ibu dengan Kejadian Stunting}

Hasil penelitian ini menunjukan tidak terdapat hubungan antara pekerjaan ibu dengan kejadian stunting pada balita $(P$ value $=0,713)$ akan tetapi balita yang berasal dari orang tua yang berkerja akan memiliki risiko 1,115 kali lebih besar untuk mengalami stunting dibandingkan dengan balita dari ibu yang tidak berkerja dengan (95\% CI 0,765-1,626). Proporsi kejadian stunting pada balita dari ibu berkerja adalah $50 \%$, sedangkan pada ibu tidak berkerja dijumpai terdapat $44,2 \%$ balita yang mengalami stunting.

Hasil penelitian ini sejalan dengan penelitian yang dilakukan Nurmayasanti tahun 2019 yang menyatakan bahwa tidak terdapat hubungan yang signifikan antara pekerjaan ibu dengan kejadian stunting pada balita, namun ibu yang berkerja akan memiliki perhatian yang kurang terhadap pola asuh anaknya dibandingkan dengan ibu yang tidak berkerja (Nurmayasanti and Mahmudiono, 2019) .

Dalam penelitian ini mayoritas ibu yang berkerja memiliki pekerjaan sebagai buruh tani sehingga mungkin akses terhadap informasi dan pengetahuan tentang pencegahan stuntingdan gizi seimbang akan kurang. Ibu yang tidak berkerja akan memiliki banyak waktu untuk anak seperti dalam hal menyiapkan makan begitu juga dengan akses informasi terkait gizi anak.

\section{g. Hubungan Tingkat Pendidikan Ibu dengan Kejadian Stunting}

Hasil analisis multivariat menunjukan terdapat hubungan yang signifikan antara tingkat pendidikan ibu dengan kejadian stunting pada balita $(P$-value $=0,048)$ serta balita yang berasal dari ibu dengan tingkat pendidikan rendah akan memiliki risiko 2,554 kali lebih besar untuk mengalami stunting dibandingkan dengan balita dari ibu yang berpendidikan tinggi (95\% CI 1,008-6,468) setelah dikontrol oleh variabel pendapatan rumah tangga dan pola asuh pemberian makan. Proporsi kejadian stunting pada balita dari ibu dengan tingkat pendidikan rendah adalah 54,3\% sedangkan pada balita dari ibu dengan tingkat pendidikan tinggi memiliki proporsi kejadian stunting sebesar 40,4\%.

Hasil penelitian ini sejalan dengan penelitian yang dilakukan di Kecamatan Padang Timur dimana didapatkan terdapat hubungan yang signifikan antara tingkat pendidikan ibu dengan kejadian stunting pada balita $(p$-value $=0,012)$, penelitian ini menyatakan bahwa balita dari ibu berpendidikan rendah akan memiliki risiko 9,9 kali lebih besar untuk mengalami stunting dibandingkan dengan balita dari ibu dengan tingkat pendidikan tinggi. Seorang yang memiliki pendidikan tinggi akan lebih mengetahui tentang pola hidup sehat termasuk dalam hal kecukupan gizi anak sehingga akan berdampak terhadap derajat kesehatan anak tersebut (Setiawan and Machmud, 2018).

\section{h. Faktor Dominan yang Berhubungan dengan Kejadian Stunting}

Faktor dominan yang berhubungan dengan kejadian stunting pada balita usia 24-59 bulan dari keluarga petani di Wilayah Kerja Puskesmas Gunung Labu Kabupaten Kerinci adalah katahanan pangan rumah tangga. Kejadian stunting di Wilayah Kerja Puskesmas Gunung Labu mayoritas berasal dari rumah tangga yang memiliki ketahanan pangan rumah tangga rendah $(73,1 \%)$. didapatkan hubungan yang signifikan antara ketahanan pangan rumah tangga dengan kejadian stunting pada balita ( $p$ value $=0,005$ ), serta balita yang berasal dari rumah tangga dengan ketahanan pangan rendah akan berisiko 4,722 kali lebih besar mengalami stunting dibandingkan balita yang memiliki ketahanan pangan rumah tangganya tinggi

SIMPULAN 
Proporsi kejadian stunting pada balita usia 24-59 dari keluarga petani di Wilayah Kerja Puskesmas Gunung Labu Kabupaten Kerinci adalah sebesar 46 balita (46,9\%) dengan prevalensi sebesar 32,34\%.

Ada hubungan antara ketahanan pangan rumah tangga dan tingkat pendidikan ibu dengan kejadian stunting pada balita usia 24-59 dari keluarga petani di Wilayah Kerja Puskesmas Gunung Labu Kabupaten Kerinci.Tidak ada hubungan antara pola asuh pemberian makan, pendapatan rumah tangga, jumlah anggota rumah tangga, pengeluaran pangan rumah tangga, dan pekerjaan ibu, dengan kejadian stunting pada balita usia 24-59 dari keluarga petani di Wilayah Kerja Puskesmas Gunung Labu Kabupaten Kerinci.

Faktor yang paling dominan berpengaruh terhadap kejadian stunting pada balita adalah ketahanan pangan rumah tangga Balita yang memiliki ketahanan pangan rumah tangga yang rendah akan memiliki risiko 4,722 kali untuk mengalami stunting dibandingkan dengan balita yang memiliki ketahan pangan rumah tangga yang tinggi setelah dikontrol oleh variabel pola asuh pemberian makan, pendapatan rumah tangga, dan tingkat pendidikan ibu.

Disarankan kepada Puskesmas agar upaya promotif dan preventif terkait gizi balita, seperti pemantauan status gizi di posyandu atau di puskesmas dan kegiatan edukasi pemberian makan untuk balita lebih dioptimalkan melalui surveilance gizi, edukasi dan pemberdayaan masyarakat, serta penguatan koordinasi lintas sektor dalam upaya pencegahan stunting.

Kepada masyarakat ataupun keluarga yang memiliki balita agar dapat mengoptimalkalkan pemanfaatan lahan pekarangan rumah dan lahan pertanian sebagai salah satu upaya meningkatkan ketahanan pangan rumah tangga sehingga memberikan makanan yang beragam, dan bergizi seimbang sehingga kebutuhan zat gizi dapat terpenuhi untuk menunjang tumbuh kembangnya.

\section{DAFTAR PUSTAKA}

Aisyah, Suyatno and Rahfiludin, M. Z. (2019) 'Faktor-Faktor yang Berhubungan dengan Stunting pada Anak Kelas Satu di SDI Taqwiyatul Wathon Daerah Pesisir Kota Semarang', Jurnal Kesehatan Masyarakat, 7(1).

Bappenas (2019a) Rencana Pembangunan Jangka Menengah 2020-2024. Jakarta.

Bening, S., Margawati, A. and Rosidi, A. (2015) 'Asupan Zink , Riwayat ISPA dan Pengeluaran Pangan Sebagai Faktor Resiko Stunting Pada Anak Usia 2-5 tahun di Kota Semarang', pp. 20-29.

BPS Kabupaten Kerinci (2019) Kecamatan Kayu Aro Barat 2018.

Isnaini, F. and Indrawani, Y. M. (2014) 'Faktor Dominan Penyebab Stunting Usia 12-23 Bulan di Posyandu Terpilih Kelurahan Depok Tahun 2014', pp. 1-19.

Jayarni, D. E. and Sumarmi, S. (2018) 'Hubungan Ketahanan Pangan dan Karakteristik Keluarga dengan Status Gizi Balita Usia 2 - 5 Tahun ( Studi di Wilayah Kerja Puskesmas Wonokusumo Kota Surabaya ) Relationship between Food Security , Family Characteristics with Nutritional Status of Children a', Amerta mm, pp. 44-51. doi: 10.20473/amnt.v2.i1.2018.44-51.

Kemenkes RI (2018b) 'Situasi Balita Pendek di Indonesia (Stunting)', in. Jakarta: Kemenkes RI.

Moehji, S. (2016) Dasar Dasar Ilmu Gizi. Jakarta: Bhratara Karya Aksara.

Nurmayasanti, A. and Mahmudiono, T. (2019) 'Status Sosial Ekonomi dan Keragaman Pangan Pada Balita 
Stunting dan Non- Stunting Usia 2459 Bulan di Wilayah Kerja Puskesmas Wilangan Kabupaten Nganjuk Socio-Economic Status and Dietary Diversity in Stunting and Non-Stunting Underfive Aged 24-59 Months i', Amerta Nutrition, pp. 114-121. doi: 10.2473/amnt.v3i2.2019.114-121.

Proverawati, A. and Wati, E. K. (2011b) Ilmu Gizi Untuk Keperawatan dan Ilmu Kesehatan. Nuha Medika.

Safitri, A. M., Pengestuti, dina R. and Aruben, R. (2017) 'Hubungan Ketahanan Pangan Keluarga dan Pola Konsumsi Dengan Status Gizi Balita Keluarga Petani (Studi di Desa Jerug Kabupaten Boyolali Tahun 2017)', Jurnal Kesehatan Masyarakat, 5(3), pp. 120-128. Available at: http://ejournals1.undip.ac.id/index.php/jkm.

Setiawan, E. and Machmud, R. (2018) 'Faktor-Faktor yang Berhubungan dengan Kejadian Stunting pada Anak Usia 24-59 Bulan di Wilayah Kerja Puskesmas Andalas Kecamatan Padang Timur Kota Padang Tahun 2018', Jurnal Kedokteran Dan Kesehatan, 7(2), pp. 275-284.

Widyaningsih, N. N. and Anantanyu, S. (2018) 'Keragaman pangan , pola asuh makan dan kejadian stunting pada balita usia 24-59 bulan', Jurnal Gizi Indonesia, 7(1), pp. 22-29. Available at: https://ejournal.undip.ac.id/index.ph p/jgi/\%0AKeragaman. 